\title{
Corporate Criminal in Prohibition of Monopolistic Practices and Business Competition Based on the Indonesian Job-Creation Act
}

\author{
Ariawan Gunadi ${ }^{*}$ Indah Siti Aprilia ${ }^{2}$ \\ ${ }^{1}$ Lecturer in Faculty of Law, Universitas Tarumanagara, Jakarta, Indonesia \\ ${ }^{2}$ Student of Master Program, Faculty of Law, Universitas Indonesia, Depok, West Java, Indonesia \\ *Corresponding author. Email: ariawang@fh.untar.ac.id
}

\begin{abstract}
Through the Job-Creation Law No. 11 in 2020 (UUCK), the government issued a new breakthrough policy by updating several articles in the law on the Prohibition of Monopolistic Practices and Business Competition. These reforms include the existence of a new policy related to the handling of cases in monopolistic practices and business competition. This research use juridic normative. The results state that the handling of disputes in monopolistic practices and business competition may be handled by the commercial court. In the UUCK, there are several articles on the abolition of sanctions and the new improvements will create more legal certainty.
\end{abstract}

Keywords: Business Competition, Corporate Crime, Job Creation Act

\section{INTRODUCTION}

The emergence of legal politics of Law Number 5 of 1999 concerning the Prohibition of Monopolistic Practices and Unfair Business Competition cannot be separated from the IMF's pressure on the Government of Indonesia. Where the IMF's pressure on Indonesia led to an agreement on January 15, 1998 which agreed that the Indonesian government would carry out various structural reforms, including deregulation of various domestic activities, the aim of which was to transform Indonesia's high-cost economy into an open competitive economy [1]. This is done in order to encourage domestic competition and expand the scope for more dynamic and efficient private sector activities, so that structural reforms emerge which include deregulation and privatization of the Indonesian economy [2].

In order to create a competitive climate in the business market in order to foster democracy in the economic field, the government requires equal opportunities for every business actor to participate in the process of producing and marketing goods and or services. This then becomes a means to realize a healthy, effective and efficient business climate in order to foster economic improvement for the implementation of just market economy. On this basis, the Indonesian government through its legal politics issued Law Number 5 of 1999 PMPU. In practice, in the business market, there are many other aspects that are involved either directly or indirectly in the business market. The existence of these attachments sometimes does not give priority to the business market, which in the end makes the business market have to submit and follow existing signs and even prioritize the business market and ignore existing regulations [3].

Law as a rule that regulates dynamic community life is needed to shape life with all social aspects, in terms of socio-political and cultural developments as economic growth. In economic activities, the law is indispensable as a barrier and regulator, it is used because of limiter resources on one side and the need for unlimited demands or needs. This is done so that there is no conlict between fellow citizens in fighting over these economic resources. It is clear that the law has an important role in economic development to realize social welfare [4].

In 2020 The government has ratified the Job Creation Law on November 2, 2020. The background for the formation of the Job Creation Law is to attract investors. Investors' interests are accommodated in the Job Creation Act. One of the benefits of the Employment Creation Law is that it creates wide employment opportunities by attracting as much investment as possible

The government considers that a new policy permit is needed to include goals for economic progress, especially in the case of Covid 19. One of the strategic efforts made in the context of realizing large employment opportunities is carried out through 3 (three) efforts, namely: (a) Increasing Investment; (b) Strengthening MSMEs; and (c) Improving the quality of Indonesia's human resources (labor). Then the Government formulated a political law called the Job Creation Law with Law Number 11 of 2020 concerning Job Creation (UUCK).

In the Job-Creation Act, there are 11 clusters including the ease of doing business and the imposition of sanctions. In addition to the 11 major clusters or fields, the job creation 
law also concerns 74 laws. One of the amended laws is the Law on Prohibition of Monopolistic Practices and Business Competition (UU PMPU).

\subsection{Paper Structure}

The rest of the paper is organized as follows. Section 2 introduces the methods that were used in this paper, while Section 3 provides the finding and discussions, and the last section is conclusion.

\section{METHODS}

\subsection{Data}

As a normative legal research, data use in this research are secondar data, that are collected through literature review. The main data are primary legal source, that consisted of law other the regulation number 11 in 2020, and regulation number 5 in 1999

\subsection{Method}

Data obtained are analysed using qualitative method. Discussions are made to understand the conception the aim of the research to the corporate criminal in prohibition of monopolistic practices and business competition based on the Indonesia job creation act.

\section{FINDING AND DISCUSION}

\subsection{Criminal Corporation}

The forms of sanctions imposed on corporations must be aimed at the benefits of criminalizing the company which does not only look at the interests of the company itself but furthermore must look at the interests of the wider community [5]. For corporate crimes, there are 3 groups of legal subjects who can be held criminally responsible, namely management, management and corporations (companies), and finally management and/or corporations (companies) [6].

Legal aspects in the application of criminal sanctions against business actors who commit fraudulent acts according to Article 379a of the Criminal Code, that business is one of the main business activities in supporting economic development, which has the same goal of getting the maximum profit. Corporations or company as subjects of criminal law can be equated with humans. Because it contains the rights and obligations that are given by law as a legal entity, and you only need to spend time with the humans who appear in it. Law beside on the Criminal Code no longer needs to regulate specifically, unless the law outside the Criminal Code wants to determine otherwise or deviate [7].

Corporate orientation has not yet been regulated by the Criminal Code and there are special laws outside the Criminal Code that regulate corporations as criminal law subjects in corporations, but appear to fill legal voids and do not guarantee legal certainty for corporate punishment. Reorientation to policy formulation on ideal corporate criminal sanctions by making corporations the subject of criminal law and emphasizing on consistency in terms of determining when a crime is said to be a corporate crime, who can be convicted of corporate crimes, and appropriate sanctions against corporations [8].

In connection with the enormous authority of the KPPU, there is another article that makes the authority/power so blunt, namely Article 44 paragraph (2) of the PMPU Law: business actors can file an objection to the District Court no later than 14 days after receiving the notification of the decision. In Article 44 paragraph (4) that business actors do not voluntarily carry out the KPPU's decision, the Commission submits the decision to investigators for investigation, and Article 44 paragraph (5) states that the commission's decision is only preliminary evidence for investigation by investigators [9].

The Business Competition Supervisory Commission (KPPU) found that there was evidence that there had been a violation of the PMPU Law by business actors, so KPPU could impose administrative sanctions on business actors who violated it. namely in the form of principal and additional penalties. The main punishment is in the form of a fine, while the additional punishment is referred to in Article 10 of the Criminal Code. Business actors found guilty may be subject to sanctions in the form of administrative sanctions or criminal sanctions [10].

This depends on the level of error of the related business actors. However, until now the KPPU is still constrained by the limited authority of the KPPU to seek evidence which consequently KPPU relies on the cooperative attitude of the complainant and business actors in seeking evidence, KPPU is not authorized to impose penalties on business actors if found guilty of violating any of the regulated matters. on the PMPU Law [11].

The CK Law simplifies the sanctions imposed on business actors who violate the Law on the PMPU. Article 47 of the PMPU Law has been amended to impose a fine of at least Rp. 1,000,000,000.00 (one billion rupiah). This article does not stipulate the imposition of a maximum fine. This reflects that the potential losses due to monopolistic practices and unfair business competition have very broad implications. So that the maximum fine limit is removed. This is explained in table 1 . The main criminal sanctions are also simplified with a maximum fine of Rp. 5,000,000,000.00 (five billion rupiah) or a minimum sentence of 1 (one) year as a substitute for a fine. In the PMPU Law, the main punishment is imposed based on the type of violation. The fines range from Rp. $1,000,000,000$, - up to Rp. $100,000,000,000.00$ or a substitute imprisonment ranging from 3 to 6 months. The imposition of basic criminal sanctions is in line with corporate criminal sanctions. In corporate crime, the priority is criminal fines. This simplification becomes clearer and provides certainty to business actors. Business actors are companies, both legal entities and non-legal entities. The Job Creation Act removes additional penalties. The PMPU Law provides 3 additional criminal sanctions, namely revocation of 
business licenses, prohibition of holding positions for actors as directors and commissioners and termination of activities or businesses that cause losses to other parties. With this abolition, business actors are punished according to the type of business, namely commerce. So that the punishment is more appropriate to be given to those who violate the PMPU Law. The idea of the CK Law is to provide large administrative sanctions with large fines to business actors. The purpose of business actors conducting monopolistic practices and business competition is to obtain the maximum profit. With this fine, the profits obtained will be used to pay the fine. Business actors will obey the PMPU Law because of the large fines. Previously, with administrative sanctions only Rp. $25,000,000,000.00$, so many corporations will still get profits after paying administrative sanctions. Even if the subject of the principal penalty is imposed, there is still a limit to the fine imposed. Additional criminal sanctions with revocation of licenses allow business actors to create new businesses with the profits earned. Ease of setting up a business, resulting in the revocation of licenses being irrelevant. Prohibition of holding positions by directors and commissioners by business actors who violate. This does not make it easier to prove and sometimes the party making the decision is not a director or commissioner, but the perpetrator is one level below the board of directors and commissioners. This additional criminal sanction becomes irrelevant as well.

\subsection{Commercial Court in resolving monopoly and business competition disputes}

The Commercial Court is also authorized to handle other commercial disputes, such as in the field of IP or we called on Intellectual Property Rights and disputes over bank liquidation processes carried out by the Deposit Insurance Corporation. The court has the function of resolving disputes in the commercial sector as regulated in Perpu Number 1 of 1998. Disputes on monopolistic practices and business competition are resolved through a commercial court based on the Job Creation Law. Based on the purpose of establishing a commercial court, commercial disputes are resolved through a commercial court.

The type of dispute in the Law on Monopolistic Practices and Business Competition is an agreement between business actors for the control of the production and or marketing of goods or services which may result in a monopoly or unfair business competition. Business people or business actor are also prohibited from entering into agreements with other business actors to determine the price for an item or service that must be paid by the customer in the same relevant market business. Business actors are also prohibited from dividing the territory that gives rise to monopolistic practices or unfair business competition. Business actors are also prohibited from entering into agreements to prevent other business actors from conducting the same business. Business actors are prohibited from conducting cartels and trusts with other business actors. In addition, agreements between business actors to control the purchase or receipt of supplies (oligopsony) are prohibited. Vertical integration, closed agreements, agreements with foreign parties, monopolies, monopsony, market control and conspiracy are prohibited under the PMPU Law.

Based on the types of disputes that may arise described above, disputes in monopolistic practices and business competition are disputes in the commercial sector. Thus, disputes over the PMPU Law should be resolved through a commercial court and not a district court. The CK Law has made the right determination by moving the dispute handled by the district court to a commercial court. The CK Law also removes the time in dispute resolution, this provides time for the parties who object. This has good effect with sufficient time to resolve objections. However, this also allows a case to take longer than before

\section{CONCLUSION}

In the settlement of business competition disputes in the commercial court, there is no time limit for dispute resolution which results in a longer settlement. However, the Indonesian creation job act offers an alternative to resolve faster and simpler and provide a better legal certainty.

\section{REFERENCES}

[1] Sutan Remy Sjahdeini. Latar Belakang, Sejarah, dan Tujuan UU Larangan Monopol. Jurnal Hukum Bisnis, 2002.

[2] Emeritus John Gilissen dan Emeritus Frits Gorle, Sejarah Hukum Suatu Pengantar, Bandung: Refika Aditama, 2005.

[3] Ahmad Yani dan Gunawan Widjaja, Seri Hukum Bisnis: Anti Monopoli, Jakarta: Rajagrafindo Persada, 2000.

[4] Susanti Adi Nugroho, Hukum Persaingan Usaha Di Indonesia Dalam Teori, Praktik, serta Penerapan Hukumnya, Edisi Pertama, Jakarta: Kencana, 2012.

[5] Ratomi, A. Korporasi Sebagai Pelaku Tindak Pidana (Suatu Pembaharuan Hukum Pidana Dalam Menghadapi Arus Globalisasi Dan Industri). Jurnal Al'Adl, 2018.

[6] Dewi, S. Perumusan Pertanggungjawaban Tindak Pidana Korporasi Dalam Berbagai Undang-Undang. Arena Hukum, 2020.

[7] Aridhayandi, M. R. Kajian tentang Penerapan Sanksi Pidana terhadap Pelaku yang Melakukan Perbuatan Curang dalam Bisnis Dihubungkan dengan Pasal 379a Kitab Undang-Undang Hukum Pidana. Dialogia Iuridica: Jurnal Hukum Bisnis, 2020. 
[8] Disemadi, H. S., \& Jaya, N. S. P. Perkembangan Pengaturan Korporasi sebagai Subjek Hukum Pidana di Indonesia. Jurnal Hukum Media Bhakti, 2019.

[9] Herlina, N. Kewenangan KPPU (Komisi Pengawas Persaingan Usaha) Dalam Penegakan Hukum Antimonopoli. Lex Lata, 2020.

[10] Herlina, N. Tinjauan Terhadap Mekanisme Penanganan Perkara Persaingan Usaha Tidak Sehat. Jurnal Ilmiah Galuh Justisi, 2018.

[11] Nastiti, G. A. Penegakan Hukum Oleh Komisi Perlindungan Persaingan Usaha Dalam Penanganan Persaingan Usaha Tidak Sehat Ditengah Wabah Covid-19. Res Judicata, 2020. 